\title{
MAGYAR IMRE ORVOSPROFESSZOR MINT ABSZOLÚT PEDAGÓGUS
}

\section{PROFESSOR OF MEDICINE IMRE MAGYAR AS AN ABSOLUTE PEDAGOGUE}

\author{
Hudra Árpád \\ filozófus, újságíró \\ hudir@t-online.hu
}

\begin{abstract}
ÖSSZEFOGLALÁS
Magyar Imre, a Korányi-iskola utolsó nagy képviselője, a Budapesti Orvostudományi Egyetem I. Belgyógyászati Klinikájának 1965-ben kinevezett igazgatója, professzora székfoglalójában azt hangsúlyozta, hogy az egyetemi klinika szorosan összefonódó hármas funkciója, a betegellátás, a kutatás és a medikusok oktatása-nevelése közül a legutóbbit tartja a legfontosabbnak. A tanulmány azt kívánja bemutatni, hogy Magyar Imre 1980-ban bekövetkezett nyugdíjazásáig abszolút pedagógusként szolgálta ennek a célkitűzésnek a megvalósítását. Már székfoglalójában az oktatás egyik legfontosabb összetevőjének tartotta a kiemelkedő tanáregyéniség által tartott előadást, amely az orvosi gondolkodásra akarja megtanítani a hallgatót. Az előadást is inkább gyakorlatnak tekintette, amely nála soha nem nélkülözhette a betegen való prezentációt. A tankönyv tehát az otthoni tanulásra volt. Magyar azonban ehhez is "segítséget nyújtott" az orvostanhallgatóknak. Funkcionális holisztikus gondolkodása lehetővé tette, hogy a specializálódott tudományokra szétváló medicinát ismét egységes, az egész emberrel foglalkozó belgyógyászatként foglalja össze Petrányi Gyulával közös, az orvosképzésben évtizedeken át használt tankönyveiben. A beteggel való konkrét kapcsolat megteremtése, a megfelelő nyelvi és metakommunikáció, az empátia, a megértés, a megfelelő orvosi magatartásmód elsajátítása nála nélkülözhetetlen feltétele volt az orvossá válásnak. Ezért is foglalkoztatta annyira az orvos személyiségének szerepe a gyógyításban, ezért végzett több alkalommal a tanulmányunkban is ismertetett vizsgálatot az orvostanhallgatók múveltségével kapcsolatban. Ezért hangsúlyozta az oktatás egészét horizontálisan és mélységében is átlátó Magyar Imre a szépirodalom, a múvészetek, a zene nélkülözhetetlen szerepét az orvos életében.
\end{abstract}

\section{ABSTRACT}

Imre Magyar, the last great representative of the Korányi School, who was appointed as the director and professor of the $1^{\text {st }}$ Department of Internal Medicine of the Budapest University of Medicine in 1965, emphasized in his inaugural address that from the three closely intertwined functions of the university clinic, i.e. patient care, research and medical training and education, he considers the last as the most important. The study intends to present that Imre Magyar, as an absolute educator, pursued this objective until his retirement in 1980. In his inaugural address he regarded lectures given by teachers of higher calibre with the intention to teach students medical thinking as one of the most important components of education. He even looked at lectures rather as seminars, never forgetting to make presentations on patients. Textbooks were 
meant for home education and Magyar, however, also 'provided assistance' with this for medical students. His functional holistic thinking made it possible that medicine as specialised sciences be once again summarised as a uniform internal medicine dealing with the whole individual in his textbooks co-written by Gyula Petrányi and used in medical training for decades. Making a connection with the patient in practice, appropriate verbal and metacommunications, empathy, understanding and showing appropriate medical behaviour were, in his view, prerequisites for becoming a doctor. That is why he was concerned about the function of the doctor's character in healing, and conducted investigations also described in this study on several occasions in relation with the general knowledge of medical students. That is why Imre Magyar, who saw the big picture of education, emphasised the vital role of literature, arts and music in a doctor's life.

Kulcsszavak: abszolút pedagógus, funkcionális holizmus, empátia, általános műveltség, személyiség

Keywords: absolute pedagogue, functional holism, empathy, general knowledge, character

Magyar Imre (1910-1984) a hazai belgyógyászat élharcosa, gyógyító orvos, kutató, tankönyvíró, kimagasló pedagógus és kiváló szépíró. Már ebből a felsorolásból is látható, hogy sokoldalú tehetség volt, ami nemcsak szakmájában nyilvánult meg, hanem humán területen is. Kérdés, hogy mindezek után tekinthetjük-e öt abszolút pedagógusnak, aki többoldalú tehetségét a pedagógia területén gyümölcsöztetve, azt önmegvalósításként élte meg, s az emberalakítás vágya jelentette léte középpontját. Látni fogjuk, hogy számára ez a kérdés a kultúra, azaz a tudomány és müvészet egységének problémáját jelentette. Ezért akart az orvosjelöltekből értelmiségit „,faragni”, s azt bizonyítani, hogy gyógyító orvosok is csak a mindenoldalú ismeretekből táplálkozó humanitás alapján lehetnek.

Magyar Imre egy zsidó család gyermekeként a felvidéki Losoncon született anyai nagyapja fogadójában, a család nem sokkal ezután visszatért eredeti lakóhelyére, Pestre. Apját, aki doktorált MÁV-tisztviselő volt, 1921-ben származása miatt eltávolították munkahelyéről, s ezután hányattatott sors várt rá. 1944-ben három öccsével együtt megölték. Imre először a Zsidó Gimnáziumban tanult, majd a különböző családi nehézségek következtében a Kölcsey Ferenc Gimnáziumban folytatta tanulmányait, és itt érettségizett. Gyermekkoráról és családjáról Az évszázad gyermeke címü könyvében számolt be. Ifjúkoráról remek öszszefoglalót írt fia, Magyar László András, az édesapjára emlékező centenáriumi emlékkönyvbe.

Életrajzi ismertetője szerint Magyar Imre későbbi pályafutására két anyai nagybátyja nyomta rá bélyegét. Deutsch Emil felvidéki német-francia szakos középiskolai tanár volt, aki eredeti nyelven olvasta a német és a francia filozófusokat, a latin nyelvü szerzőket, s munkáikhoz is mindig az adott nyelven írt jegyzeteket. A másik nagybácsi, Deutsch Zsigmond tíz nyelven tökéletes kiejtéssel beszélö fogorvos, aki alkalmanként a bécsi Operaház zenekarában is csellózott. Minde- 
mellett nagyszerüen rajzolt és festett is. Magyar László András szerint édesapját a bölcsészet és az orvostudomány egyaránt vonzotta. Döntését az utóbbi mellett végső soron az határozta meg, hogy zsidó származású ember tanári állást nemigen kaphatott a 30-as években. Megjegyezzük, ez a kettős hatás, amely Magyar Imrében egyesült, sok mindenre genealógiai magyarázatot ad abszolút pedagógusi pályafutása szempontjából.

Az ifjú Magyar Imrére jellemző volt az irodalom és a zene szeretete. Magyarul és franciául egyaránt sokat olvasott. Ezenkívül írt verset, verses színdarabot, novellát, cikkeket, tudósításokat. Verlaine-fordítása már gyakorló orvos korában jelent meg a Magyar Hírlapban. A zenére visszatérve: jól hegedült, játszott a gimnázium, majd az egyetem medikus zenekarában, rendszeres hangversenyhallgató volt.

Mindezek után rá kell térnünk arra, hogy a numerus clausus ellenére hogyan is vették fel 1928-ban a Magyar Királyi Pázmány Péter Tudományegyetem orvosi karára. Ebben, kiváló bizonyítványán túl, némi professzori segítség is szerepet játszott, sőt apja tisztviselői múltja alapján tandíjmentességet is kapott.

Egyetemi pályafutását $A$ kérdés címü kötetében megjelent, Így lettem orvos címủ írása alapján tudjuk nyomon követni.

Visszaemlékezésének elején bevallja, hogy sohasem tartotta magát természettudósnak, jóllehet tudja, hogy a szakmai tudás az orvoslás alapja. A gyógyításban ugyanakkor nagy szerepet tulajdonított az emberi magatartásnak.

Az egyetemen három tanár volt rá igazi hatással, Lenhossék Mihály (aki egyébként Szent-Györgyi Albert anyai nagybátyja volt) az anatómia, Farkas Géza, az élettan professzora és mindenekelött Korányi Sándor, akinek belgyógyászati előadásait hallgatta. Nagyra becsülte Hetényi Gézát, Korányi adjunktusát is, akinek vizitjein tanulta meg, hogy mennyire fontos szerepet játszik az orvos emberi lényének milyensége a beteggel való kapcsolatban, a gyógyításban. Olyan orvos szeretett volna lenni, mint ö - írta. Korányiról és Hetényiröl a későbbiekben még részletesebben is szólunk. Magyar egyébként tanulmányai közül a kórbonctant tartotta az egész orvostudomány alapjának. Itt ugyanis, azt követően, hogy az élő emberen észlelték a betegség különböző tüneteit, ezeket a tüneteket részletesen szemügyre lehetett venni a szerveken, idegeken és ezek szövettani metszetein.

Magyar Imre medikusként többször is gyakornokoskodott a Korányi-klinikán. Itt egyértelmüvé vált számára, hogy belgyógyász akar lenni, azonban nem gyakorló orvosként. „Vágyam mindig elsősorban a tanítás volt” - jelenti ki határozottan önéletrajzi írásában. Ennek alapján úgy gondoljuk, hogy Magyar megfelel az abszolút pedagógus második kritériumának is, amelyről tanulmányunk elején szóltunk. Azaz az önmegvalósítás terepe számára a pedagógia lett.

Feltette magának azt a kérdést is, hogy miért akar egyáltalán orvos lenni, amikor különösképpen nem is vonzódik a természettudományokhoz, ami pedig végső soron ilyen pálya. Önmagának adott válasza az volt, hogy azért, mert szereti 
a beteg embert, sajnálja, megérti, és minden erejével igyekszik gyógyítani, vagy állapotán, félelmein, hangulatán enyhíteni. Orvosi ars poeticáját szó szerint idézzük. „És úgy látom, hogy egyelőre a betegek nagy részét nemcsak a természettudomány eredményeivel gyógyítjuk, hanem elsősorban viselkedéssel, beszéddel, ráhatással. Egyelőre csak nagyon kevés olyan betegséget láttam, amelyet meg lehet gyógyítani. A malária volt ilyen, vagy a szifilisz, meg néhány szérumokkal gyógyítható vagy oltásokkal megelőzhető fertőző betegség. A többi beteget csak kezeltük, noha hitt bennünk, és a gyógyulást tőlünk várta. Úgy is tettünk, mintha gyógyítanók, holott legfeljebb csak gyógyult."

Magyar Imrének, ahogy ő írta, még az egyetem elvégzése előtt sikerült majdnem megismernie, de legalábbis alkalmaznia Hetényi titkát a betegekkel való bánásmód tekintetében. Ö is tudott hatni a betegekre, amit szerinte nem annyira különleges tehetségének vagy képességének köszönhetett, hanem annak, hogy tudta, a betegekért van, s egyetlen és legföbb feladata, hogy hasson rájuk betegségük megkönnyítése érdekében.

Itt fedezi fel azokat a tudástranszfereket, amelyek az abszolút pedagógus legfőbb jellemzői közé tartoznak. Magyar határozottan tudta, hogy mennyit segít neki széles szépirodalmi olvasottsága, mivel olvasmányainak szereplöit már eleve azonosítani volt képes egy-egy betege személyiségével. Így már előre tudta, hogy hogyan és miről beszéljen velük. Teljes bizonyossággal érezte azt is, hogy a zene megkönnyíti számára „az eredetileg idegen lélek megközelítését, megismerését és a beleélésnek azt a folyamatát, melyet ma empátiának szokás nevezni”.

Azt, hogy az abszolút pedagógus hogyan „,készülődött” Magyar Imrében, mutatja, hogy még ötödéves kora előtt a szigorló orvosok felkérték, készítse fel öket a szigorlatra. Ezt szívesen vállalta, mert „nagyon szeretett tanítani”. Ez azzal a nyereséggel is járt, hogy megtudta, miben vannak ismereti hiányosságai, s ezeknek alaposan utána kellett járnia.

Már végzős hallgatóként olvasta Adolf Strüpell klasszikus német belgyógyászati könyvét, s visszaemlékezése szerint ekkor ébredt fel benne a vágy, hogy ne egy-egy elmaradt szigorlót tanítson belgyógyászatra, hanem medikusok százait. Ugyancsak ekkor kezdte el foglalkoztatni a gondolat, hogy a magyar orvostanhallgatóknak egy jó belgyógyászati tankönyvet kellene írni. 1934-ben kapta meg orvosi diplomáját a tizenöt legjobb végzős egyikeként.

Magyar Imre a Korányi-iskola utolsó nagy képviselöje volt. Amennyiben mint abszolút pedagógust kívánjuk ôt meghatározni, akkor mindenféleképpen érdemes röviden áttekintenünk, hogy mit is jelentett ez a bizonyos iskola, kik voltak azok a nagy emberek, akiket képviselőinek, megőrzőinek és továbbfejlesztőinek tekintünk. Ezt annál könnyebben meg tudjuk tenni, mivel Magyar Imre maga volt az, aki a nagyok majdnem mindegyikéről, Korányi Frigyesről, Korányi Sándorról, Hetényi Gézáról visszaemlékezést, tanulmányt, kismonográfiát írt. Ezért őt akár orvostörténésznek is nevezhetnénk. 
Az igazán fontos számunkra az, hogy ez egy önmeghatározási folyamat bemutatása is, hogy mit jelentett neki a nagy emberek öröksége. Azt is mondhatnánk, Magyar teljesen tudatában volt annak, hogy ő abszolút pedagógus, jóllehet ezt a fogalmat még nem használhatta.

A Korányi-iskola tulajdonképpeni megalapítója Magyar Imre szerint a nagykállói izraelita orvoscsaládba született Korányi Frigyes (1828-1913), az egykori márciusi ifjú, az 1848-49-es forradalom és szabadságharc résztvevője, aki 1880ban lett a pesti egyetem I. számú Belgyógyászati Klinikájának vezetője, s ezt a tisztséget egészen 1908-ig töltötte be. Nagy orvossá az tette, hogy a tudományt mindig össze tudta kapcsolni az élettel, s a kettő közös nevezője mindig a beteg ember volt. Munkássága magában foglalta a magyar belgyógyászat megalapozását és a magyar egészségügy fejlesztését.

Korányi Frigyes fia, Korányi Sándor (1866-1944) 1888-ban végezte el a budapesti egyetem orvosi fakultását. Magyar szerint Korányi Sándor számára atyai örökség volt a közösséggel és azon belül az egyes emberrel való törődés. Ugyanakkor Sándor, a legnagyobb magyar belgyógyász, ahogyan sokan tartják, különböző természettudományi ágakra is kiterjedő külföldi tanulmányútjai eredményeként, valóban paradigmaváltást hajtott végre a hazai orvostudományban. Magyar ezt így fogalmazza meg a legtömörebben: „Ha Korányi tudományos érdemeinek lényegét röviden akarnók összefoglalni, azt mondhatnók, hogy Korányi Sándor a fizika, kémia módszereinek alkalmazásával, a kórtani gondolkodásmóddal a funkcionális [működési - H. Á.] patológia megalapozója és kifejlesztője.” Apja nyugalomba vonulása után, 1909-ben vette át a klinika vezetését, amely aztán nem eredeti helyén, hanem kétszeri költözéssel, III. számú Belklinika néven müködött 1936-os megszüntetéséig.

Magyar Imre 1932-ben, harmadéves orvostanhallgatóként került a klinikára, majd végzése után is ott dolgozott egészen a megszüntetéséig. Kismonográfiájában megemlíti, hogy 1936-ot követően is a klinika szellemében élt tovább, abban a Stefánia úti Belgyógyászati Intézetben, amelyet Hetényi Géza, Korányi utolsó adjunktusa vezetett, addigi orvoskollégáit is maga mellé véve, s ahol Korányi Sándor is szinte napi rendszerességgel vizitelt.

Mi a Korányi-iskola lényege? - teszi fel a kérdést Magyar. A tudományos gondolkodásmódot említi, hozzátéve a kórteremben kitüzött célok alapján a klinikán folyó kísérletezést, s aztán az eredmények felhasználását ugyancsak a kórteremben. Továbbá a törekvést az egzaktságra, a kifejezés világosságára, a szigorú kritikára a gyógyításban és a tudományos kutatásban és nem mellesleg a tudományos tisztességet. Ahogy megfogalmazza, mindez Korányi Sándorból sugárzott, ugyanúgy, mint az optimista hozzáállás a tudományos haladáshoz, a terápiába vetett hit, az eredményesség biztos tudata. Humanizmusa és „morális felfogása” alól senki nem vonhatta ki magát.

Milyennek látta Magyar Korányi Sándort mint tanárt? Életének középpontját jelentették a kitűnő szerkezetű, klasszikus szépségű, csodálatos logikájú minden- 
napos előadások. Az elhangzottakat azonnal nyomdába lehetett volna küldeni. Magyar szerint Korányi végtelenül szerette a medikusokat.

Egészében úgy összegezte, hogy Korányi derüsen, agilisan, fáradtságot nem ismerve tanított és gyógyított. „Gazdag volt ötletekben, ugyanakkor volt képessége a legmagasabb szintézisre is, és valójában ez adta a Korányi-iskola nagyságát: az experimentális ötletesség és a kritikus szintézis összefonódása.”

Magyar Imre - mint már említettük - tanítványként követte Hetényi Gézát az 1936-tól 1944-ig müködő Stefánia úti belgyógyászati magánintézetbe. Hetényi szellemi erejét alapvetően az összefüggések felismerésében, a tiszta, világos logikában, a magasabb rendủ szintézis megteremtésében látta. Magatartásából az sugárzott, hogy mindenki egyenértékủ ember, orvos nem nézheti le a beteget, főnök a beosztottját, beteg a másik beteget. Ezért szorgalmazta Hetényi Géza a tanítványainál, hogy ne csak a szakmával foglalkozzanak. Fontos a jó könyvek olvasása, a zenehallgatás, a képzőmüvészet alkotásaiban való gyönyörködés, s egyáltalán az, hogy minden összefüggésében ismerjék meg az embert.

Később látni fogjuk, hogy mindaz, amit Magyar Hetényiről írt, hogyan tért vissza az ő abszolút pedagógusi tevékenységében.

Ahhoz, hogy tovább vizsgálhassuk, Magyar Imre abszolút pedagógus volt-e, át kell tekintenünk, hogyan gondolkodott a belgyógyászatról, annak helyéről, szerepéről az orvostudományban, az oktatásban. Úgy látta, hogy a specializálódás már régen túlnőtt a belgyógyászaton. Ugyanakkor a specializálódás nem lehet az orvosképzés alapja. A képzés alapelve, hogy a beteget kell gyógyítani, a medicinának pedig az ember szolgálatában kell állnia. Ezt biztosítja a klasszikus belgyógyászat, amely „„összefüggéseiben, egészként látja az embert és betegségeit”. Ezért van szükség a magas képzettségü belgyógyászokra, akiknek „,gondolkodásmódja", tevékenysége megakadályozza, hogy a medicina specializálódott területekre, szakokra hulljon szét.

Ezután érdemes megnéznünk, hogy Magyar Imre hogyan tervezte meg és milyen eredménnyel a belgyógyászat oktatását 1965/66-ban harmadéves hallgatóknak hat félévre az általa vezetett I. számú Belgyógyászati Klinikán. Erről A belgyógyászat oktatásának tapasztalatai címü írásában számolt be 1968-ban a Felsőoktatási Szemlében. Elgondolásainak lényege, hogy a tanítás nem a belgyógyászati tankönyv egyes szervrendszerek betegségei bemutatásának szisztematikus rendjét követte. Sőt kifejezetten az volt a cél, hogy ezt elkerüljék. „Az előadások témáját mindig az éppen rendelkezésre álló betegek szabták meg, és minthogy a jelenlegi betegfelvételi rendszer nem teszi lehetővé azt, hogy bizonyos időre bizonyos betegek rendelkezésünkre álljanak, csak azt a megoldást követhettük, hogy egy-egy, az oktatás szempontjából fontosabb beteg, érdekes diagnosztikus probléma, ritka betegség esetében az előadások fonalát megszakítva egyéb, esetleg más félév anyagába tervezett témát választottunk. Igyekeztünk a lehetőségekhez képest azt is megoldani, hogy a hat félév alatt a belgyógyászati betegségek vala- 
mennyi formája egyszer, de lehetőleg többször elöadásra és bemutatásra kerüljön. Azt sem állíthatjuk, hogy minden egyes betegség szerepelt volna az előadásokon, de ez nem is volt kitüzött célunk. A belgyógyászat előadásának nem lehet feladata a meghatározott anyag rendszeres előadása. A cél, amelyet követni óhajtottunk, a diagnózis menetének, a betegségek létrejötti módjának, a gyógyítás elveinek, az azonos tünetü, de különböző eredetű betegségek elkülönítésének bemutatása és az orvosi gondolkodásra való nevelés." Mindez azt jelenti, hogy a tantermi előadás nem elméleti volt, különválasztva a gyakorlattól, sőt inkább gyakorlatinak volt tekinthetö. Magyar szerint az ilyen „megbeszélések” során közvetlen kapcsolatot lehetett kiépíteni a hallgatókkal. „Az előadás tehát a bemutatott beteg vagy betegek egyéni betegségével vagy a betegség egyéni vonásaival foglalkozik, megtanítja a hallgatót arra, hogy ne csak a szervi elváltozásokkal, hanem az egész emberrel foglalkozzék, bevezeti a hallgatót - anélkül, hogy erre kitérne - abba a nagyon bonyolult és a gyógyításhoz okvetlenül szükséges viszonyba, amely az orvos és beteg között kialakul, és megtanítja arra, hogy miképpen bánjon az orvos a beteggel, hogyan nyerje meg bizalmát, és milyen módon viselkedjék ahhoz, hogy ne váljék fölényessé vagy személytelenné. Az előadás természetesen csak akkor lesz maradandó hatású, ha az egyedi betegre felépített és alkalmazott mondanivalók után a hallgató otthon előveszi a megfelelő tankönyvet, és most már a betegség általános képével és a szükséges adatokkal jön tisztába. Az említett módon kialakított előadás, amelyben az előadó tapasztalatából és emlékezetéből származó illusztrációk is szerepelnek, és amelyre az előadó egyénisége is rányomja bélyegét és ezáltal maradandó, az egész élet folyamán felhasználható emlékképeket kelt, valójában egyáltalán nem nevezhető elméletinek, mert hiszen minden mondatában a gyakorlati tevékenység és a gyakorlatban követendő gondolkodásmód elsajátítását teszi lehetővé, miközben gyakorlati nevelő hatást is kifejt." A kórtermi gyakorlat a klinikavezető szerint „csak” annyiban különbözött az előadástól, hogy itt a medikusok személyesen vizsgálhatták meg a betegeket, a megbeszélések viszont nem voltak olyan részletesek. A tapasztalatok tehát azt mutatták, hogy „a hallgató az életre való felkészülésében jó tantermi előadásból sokkal többet profitál, mint az ún. gyakorlatból". Magyar ugyanakkor nem nevezte megbízhatónak a hallgatók tudását az elméleti alaptárgyakból, mint az anatómia, élettan, kórbonctan, kórtan, ami így nehézzé tette számukra a klinikai tárgyak, így a belgyógyászat hallgatását. Ezért az elméleti képzés erősítését tartotta fontosabbnak, mint a gyakorlati oktatás szorgalmazását. Kérdőjelet tett amellé is, hogy a túlzott laboratóriumi vagy elméleti intézeti munka nem ment-e az általános képzettség rovására. Kifogásolta a nem hallgatott tárgyakból való állandó vizsgáztatást is. Ez ugyanis megakadályozza ,a hallgatók ambíciójának, érdeklődésének kifejlődését, és gátja annak, hogy az önálló gondolkodás képessége, amely az orvos személyiségének egyik legszükségesebb tartalmi vonása, kialakuljon”. Végső konklúziója, hogy a belgyógyászat oktatásának centrumában továbbra is a tantermi előadásnak 
kell állnia abban a formában, ahogyan az előbbiekben vázolta. Vizsgázni pedig a régebbi rendszer szerint, az ötödik félév végén kellene, amikor a hallgató az alapképzést már alapos klinikai stúdiumokkal egészítette ki. Magyar felhívta a figyelmet: eljött az ideje annak, hogy az orvosi képzésben ne csak az átlagorvosok, hanem a kiválók nevelésével is foglalkozzanak. A nevelésben szintén az előadás játszhatja a legfőbb szerepet, amelynek biztosítéka „főképp az előadó egyéniségében, szuggesztivitásában, előadásának tartalmában és az előadást füszerező és élvezetessé tevő, néha jelentéktelennek látszó, mégis sokszor mély nyomot hagyó megjegyzéseiben és élményanyagában rejlik".

Érdemes megnézni, hogy majdnem egy évtizeddel később, 1975-ben, hogyan vélekedett Magyar ugyanezen kérdésekről A tanitási-tanulási folyamat elemzése az orvosképzésben című vitacikkében ugyancsak a Felsőoktatási Szemlében, amely Lezák György és Tigyi András vitaindítójához való hozzászólás volt.

A vita elindítói a megnövekedett ismeretanyagot akarták egységes elv szerint az orvosképzés tanítási-tanulási folyamatába, az utóbbi erősítésével, beépíteni. Oktatási témánként ez úgy nézett volna ki, hogy először lenne a figyelemfelhívó, tájékoztató jellegü bevezető előadás, azután következne programozott módon, tesztkérdésekkel a tankönyvből való tanulás, majd a csoportos foglalkozás a laboratóriumban, illetve a betegágynál előzetes teszttel és utólagos ellenőrzéssel. Végezetül tartanák meg a témazáró előadást, amely az összefüggéseket értelmezné. Magyar szerint a belgyógyászatot lehet az egyes szervek betegségei, a rendszerbetegségek, az eredet szerinti betegségek alapján rendszerezni. Mindezt meg lehet tanulni a vitaindítók által javasolt elvek szerint, az elméleti tárgyakra alapozva, programozva vagy anélkül. Mindebböl azonban nem lehet megtudni, hogy mi a belgyógyászat, ahogyan azt megelőzően ismertetett tanulmányában összefoglalta. Az előadás szerinte nem bevezetés vagy figyelemfelhívás és öszszefoglalás. Tekintélyes belgyógyász professzoroknak kellene ezt tartaniuk, akik egyéniségük, tapasztalataik révén megtanítanak a megfelelő gondoldásmódra, átadják a szakma iránti lelkesedést, felvázolják a tankönyvben még nem szereplö információkat, rámutatnak a tisztázatlan kérdésekben a kutatás irányára, a társadalmi vonatkozásokra. A programozott tankönyvek az önálló gondolkodás ellen vannak, csak bizonyos alapismeretek megtanulásában hasznosak. Az egyéni tanulásban éppen az a fontos, hogy a hallgatók képességeiknek és hajlamaiknak megfelelően, maguk szabják meg tanulásuk módját és formáját. Ehhez sok ismeretet tartalmazó, a nyitott kérdéseket is bemutató, elméleteket felsoroló tankönyvre van szükségük, amely gondolkodásra, ítéletre, válogatásra ösztönzi őket.

Végezetül leszögezi, amíg az oktatás gerincét jelentő belgyógyászatból az ötödik évfolyamon egyszer egy héten tartanak előadást, nem lehet semmiféle nevelöhatást, érdemi oktatást, a hallgatókkal való közvetlen kapcsolatot elvárni.

Magyar a csoportos foglalkozást csak a tantermi előadás kiegészítőjeként tudta elképzelni. A nagy előadások egy részének viszont szemináriumi jellegünek 
kell lennie. Összegzésképpen kijelentette: „Tudatában vagyok annak, hogy a mai belgyógyászat sokban különbözik a negyven év elöttitől, de azt is tudom, hogy alapjában és lényegében nem. Az akkor elsajátítandó ismeretanyag minden látszat ellenére nem volt lényegesen kisebb, mint a mai. Így határozottan állítom, hogy a magam medikus idejében, amikor a hét minden napján Korányi Sándor ragyogó előadását hallgattam és ugyancsak a hét minden napján délután 4 órától 5-ig a belklinikán kiscsoportos gyakorlaton vettem részt, annak ellenére, hogy magyar nyelvü tankönyv nem volt, az oktatás lehetö legmagasabb hatásfokával élhettem.”

Az eddig ismertetettekből is kiderül, hogy Magyar Imre a humán, a müvészeti és a társadalmi tudásanyagot is transzferálta előadásaiba és az általa vezetett gyakorlati foglalkozásokba is. Ez tette pedagógiai tevékenységét az abszolút pedagógusra jellemző módon világszerüvé.

Azt, hogy ezt mennyire fontosnak tartotta, mutatja, hogy még 1970-ben saját maga készített felmérést orvostanhallgatók között arról, hogy mennyiben vannak birtokában a véleménye szerint az általános müveltség körébe tartozó ismereteknek. Úgy gondolta, mindez azért fontos, mert a medikusok későbbi életüket a foglalkozásukon belül a humánumnak fogják majd szentelni. A felmérés eredményeit Orvostanhallgatók általános müveltsége címmel a Valóság címü folyóiratban tette közzé 1971-ben. Magyar kérdései az általánosan használt kifejezések magyarázatára, nyelvismeretre, filozófiai ismeretre, mitológiára, irodalomra, zenére, képzőművészetre, a szellemi irányok általános ismeretére, történelemre, földrajzra, némi technikai ismeretre, matematikára és a napi politikára vonatkoztak. Nem ismertethetjük a vizsgálatról szóló beszámoló részleteit. A kérdésekre a 400 fös negyedéves évfolyamból 128-an voltak hajlandóak válaszolni. Utóbbiak közül 14-en tartoztak a legmüveltebbek közé, 23-an egészen müveletlenek voltak, és így 91 föt tett ki a nagy szürke átlag. Az említett területek között a rájuk vonatkozó ismeretek mértékét tekintve nem volt igazán különbség. Magyar konklúziója szerint nem vitás, hogy a humán müveltség több oknál fogva is hanyatlóban van. Ebbe azonban az orvostanhallgatók esetében nem lehet belenyugodni, hiszen nekik az egész embert kell ismerniük, minden vonatkozásában. Ezért véleménye szerint szükséges a változtatás.

A felmérés, különösen az orvostársadalom részéröl, heves bírálatokat váltott ki. Voltak azonban olyanok, akik látták, hogy az oktatói frusztrációk, a nemzedékek közötti szakadék felismerése vezette Magyart a sokak által maximalistának és lexikálisnak tartott felmérés elvégzéséhez. Érdeméül tudták be, hogy müveltségvizsgálatával követ dobott az állóvízbe. Magyar a vita végén akként összegezte indítékait, hogy úgy érezte, ,nagyobb körben is érdemes felhívni a figyelmet arra, hogy valami nincs, ami volt, amiért kár, és aminek a helyébe még más nem lépett".

1979-ben Orvos és müveltség - kapcsolatos feladatok az orvosképzésben címmel tanulmányt írt a Felsőoktatási Szemlébe. Azt írta, hogy mivel az orvos közvetlenül kerül kapcsolatba az emberrel, ugyanúgy, mint a pedagógus vagy a bíró, 
ezért feltétlenül szükséges, hogy a szakmai tudáson kívül általános müveltséggel, kiváltképp humán müveltséggel rendelkezzen. Nem fejtette ki, hanem csak megjegyezte, hogy az általános müveltségen belül „nagyon is mesterségesen” tesznek különbséget a természettudományos és a humán müveltség között. Elmondta, hogy most ötödéves hallgatókat kért meg arra, hogy az orvos müveltségére általában és a maguk mủveltségére vonatkozóan néhány kérdésére válaszoljanak. Négyszáz hallgatóból mindössze százan vállalkoztak erre. Magyart meglepte, hogy sokan válaszoltak úgy, hogy az orvosoknak annyi általános müveltségre van csak szükségük, mint minden más embernek. Habár a válaszadók többsége pozitívan foglalt állást, Magyar mégis balul sikerültnek tartotta a felmérést, amelynek eredménye egészében nem tükrözi a „kiművelt emberfők” ideálját. Véleménye szerint a középiskolában kellene szert tenniük a hallgatóknak az általános müveltségre. Az egyetem ennek szükségletét még felkelthetné, de nagy oktató egyéniségek hiányában ezt nem teszi.

A pozitív válaszokat a következőképpen foglalta össze. Az orvos igen közeli emberi kapcsolatba kerül a beteggel, de a gyógyítás tudományos eszközei még gyakran ma is felmondják a szolgálatot, és ilyenkor válik igen fontossá az emberség, a személyiség, az egyéniség. Utóbbiak alapja pedig az ismeret a világról, a társadalomról, az emberről. Több kell tehát mint emberismeret, lélektan, empátia. Itt érdemes szó szerint idézni a tanulmányból, mert az nyilvánvalóan nemcsak a hozzászólók, hanem Magyar Imre véleményét is tükrözik: „Az ember és a világ ismerete csupán saját tapasztalatok alapján alig lehetséges. Csak az irodalom segíthet, amely az emberi helyzetek gazdag tárháza és amelynek széles körü ismerete képessé teszi az orvost arra, hogy bármilyen szituációban jól kiismerje magát. A beteg érzésvilágának megértéséhez pedig a többi müvészet teszi fogékonnyá a lelket, a zene, a képzőművészet, a mozgásművészet stb.” Továbbá: „A megfelelő hang meglelése, a kapcsolat létesítése a szenvedő emberrel, az a humánum, amely a tudáson kívül a gyógyításhoz szükséges, az ismeretek folyománya. Csak az az orvos gyógyíthat eredményesen, aki hisz munkája értelmében, híve a jónak, szépnek, igaznak, egészséges, optimista lelkivilágot alakít ki magában, kiegyensúlyozott, és nyugalmát másoknak is át tudja adni."'

Magyar szerint az az érv is szerepelt a válaszok között, hogy magán a szakmán belüli magas színvonal megtartásához, az állandó továbbhaladáshoz, továbbképzéshez , az ismeretek befogadásának olyan képessége szükséges, amelyet az általános müveltség tesz lehetővé”. A müveltség azonban nemcsak ezt teszi lehetővé, hanem azt is, hogy az ember ki tudja alakítani azokat a képességeit, amelyek az emberi lét értelmét, a munkát, a törekvést valaminek az elérésére, $\mathrm{s}$ a boldogság érzését, mint ideálokat valóban ideálokká teszik. Magyar szerint a müveltségre való ösztönzést már otthon, illetve az iskolában el kellene kezdeni, ez nem lehet a felsőoktatás célja, sokkal inkább az egyetemen kívüli kulturális élet adhatna megfelelő inspirációt. 
Végezetül hadd pótoljuk azt, hogy tanulmányunkban nem esett még szó arról, hogy tanítványai hogyan viszonyultak Magyar Imréhez. Elöször is úgy, hogy harmincnyolc éven át orvosnemzedékek tanulták a belgyógyászatot a tizenegy kiadást megélt, Petrányi Gyulával közösen írt, A belgyógyászat alapvonalai címü könyvből. Az első kiadás 1948-ban, az utolsó 1986-ban jelent meg. Tanítványai közül sokan emlegették rendkívüli múvészet- és zeneszeretetét, szóvicceit, azt, ahogyan hatással volt gondolkodásmódjukra, cselekedeteik szándékára és irányára, egyáltalában egyéniségük fejlődésére. Nagy élményt jelentettek számukra azok az alkalmak, amikor az egész klinikát meghívta leányfalui nyaralójukba.

Összegzésképpen elmondhatjuk, hogy Magyar Imre horizontálisan és mélységében is átlátta az orvosi oktatási folyamat egészét. Tudástranszferei a psziché világától, a magatartásformák megfigyelésén át az oktatáspolitikáig terjedtek. Emberképe egyaránt figyelembe vette a természettudományos és a humán kultúra nézőpontját. Valóban abszolút pedagógus volt.

\section{IRODALOM}

Honti J. (szerk.) (2010): Magyar Imre centenáriumi emlékkönyv. Budapest: Medicina Könyvkiadó Lezák Gy. - Tigyi A. (1975): A tanítási-tanulási folyamat elemzése az orvosképzésben. Felsőoktatási Szemle, 24, 12, 728-734.

Magyar I. (1968, 1969): Kozmikus sértődés. Budapest: Medicina Könyvkiadó, 18-19.

Magyar I. (1968): A belgyógyászat oktatásának tapasztalatai. Felsőoktatási Szemle, 17, 11, 669-675.

Magyar I. (1970): Korányi Sándor. Budapest: Akadémiai Kiadó

Magyar I. (1971): Orvostanhallgatók általános műveltsége. Valóság, 14, 26-38.

Magyar I. (1975): A tanítási-tanulási folyamat elemzése az orvosképzésben. Hozzászólás Dr. Lezák György és Dr. Tigyi András vitaindító cikkéhez. Felsőoktatási Szemle, 24, 12, 728-734.

Magyar I. (1977): Korányi Frigyes. Orvosi Hetilap, 118, 50, 3007-3010.

Magyar I. (1979): Orvos és müveltség - kapcsolatos feladatok az orvosképzésben. Felsőoktatási Szemle, 28, 1, 641-644.

Magyar I. (1981): A tanítvány szemével: Hetényi Géza. Orvosi Hetilap, 122, 32, 1975-1977.

Magyar I. (1984): A kérdés. Budapest: Szépirodalmi Kiadó

Magyar L. A. (2010): Magyar Imre életrajza - gyermek- és ifjúkor. In: Honti J. (szerk.): Magyar Imre centenáriumi emlékkönyv. Budapest: Medicina Könyvkiadó, 72-76. 